How Product Attributes Affect Consumer Decision To Purchase A Premium Scooter Matic?

by Yudi Helfi, Fatihatul Akbar, Dinda Mutiara Pratiwi, Fakhri Mujahid Maolani

\title{
How Product Attributes Affect Consumer Decision To Purchase A Premium Scooter Matic?
}

\author{
Yudi Helfi *) \\ Fatihatul Akbar **) \\ Dinda Mutiara Pratiwi ***) \\ Fakhri Mujahid Maolani ****)
}

\begin{abstract}
The automotive industry is one of the industries with the largest growth rate in Indonesia. The motorcycle is chosen as the most favorite means of transportation due to their superiority in affordability, maintenance costs, fuel costs and effectiveness of travel time. Among companies that compete fiercely for this market niche are PT. Astra Honda and PT. Yamaha Indonesia Motor Manufacturing. Both of them recently launched a new variant in the premium automatic scooter segment namely Yamaha NMax $155 \mathrm{cc}$ and Honda PCX $150 \mathrm{cc}$. Although Honda dominates the scooter market segment in general, the AISI data in the early semester of 2018 shows that the achievement of sales of Honda PCX is far behind their closest competitor, Yamaha NMax in the range of 2:8. So that it becomes interesting for the researchers to know the perceptions of quality, features, style, and design of Honda PCX's attributes on consumer decisions in purchasing related products. Respondents involved in this study were 60 members of the HPCI (KAPURSUCI) community in Karawang, Purwakarta, Subang and Cikarang using non-probability sampling techniques, which is accidental sampling on filling each questionnaire. The results of this study conclude that there is a positive influence between product attributes possessed by Honda PCX (quality, features, and product design) on the purchasing decisions.
\end{abstract}

Keywords: Product Attributes; Purchasing Decisions; Product Quality; Product Features; Product Style; Product Design

\section{INTRODUCTION}

\subsection{Research Background}

Indonesia is one of the countries in Asia that has significant growth in the automotive sector with a prediction of total sales of around 2.3 million vehicles by 2019 . Motorcycles are the favorite transportation mode used by the community due to the superiority in terms of affordability, fuel costs, the effectiveness of travel time, comfort and ability to break through traffic jams on the highway (Setiawan, 2013). In addition, the increasing number of motorized vehicle ownership is also caused by the ease of purchasing requirements (low down payment and installment) and limited public transportation.

Data from the Indonesian Motorcycle Industry Association (AISI) in 2018 showed that although Honda was still the leader of the scooter motorcycle market in Indonesia, Honda recorded a decline in market share of around 3-4\% at the beginning of 2018. This is what made Honda recently launched a new variant to the automatic premium category named Honda PCX $150 \mathrm{cc}$. This automatic motorcycle by Honda does look different in general; the design is deliberately made bigger and wider to give a more sporty and stylish impression, supported by a variety of solid color choices in the motorcycle body. (Fransiska \& Seminari, 2018). Honda PCX $150 \mathrm{cc}$ has also been equipped with eSP technology (enhanced smart power), ACG starter, and is equipped with 
advanced features, including Idling Stop System, Combined Brake System (CBS), PGM-FI, Antitheft alarm, automatic side stand, magnetic ignition, and cellphone charger. The ISS feature in the Honda PCX $150 \mathrm{cc}$ is claimed by Honda to be a superior feature that is not yet available in other premium scooters. Honda PCX $150 \mathrm{cc}$ also has the advantage value for money because it has more complete features but with an affordable price. It is hoped that the offer of comprehensive product attributes can restore Honda's dominance in the scooter market segment.

Evaluating product attributes is one of the most important stages for consumers before making a purchase decision. Product attributes and purchasing decisions are a relationship that affects each other. Therefore, based on the description of the background presented, the author is interested in conducting research entitled How Product Attributes Affect Consumer Decision To Purchase An Automotive Product?

\subsection{Research Problem}

Based on the research background, the formulation of the problem of this study is how the product attributes that consist of quality, features, and style and design effect on the purchase decision of premium automatic scooter, Honda PCX $150 \mathrm{cc}$ ?

\subsection{Research Purpose}

Based on the formulation of the problem, the authors formulated several objectives of the study to find out how the product attributes that consist of quality, features, and style and design affect on the purchase decision of premium automatic scooter, Honda PCX $150 \mathrm{cc}$.

\section{THEORETICAL FRAMEWORK AND HYPOTHESES DEVELOPMENT}

There are several previous studies that are used as references in this study (see Table 1).

Table 1 Previous Research

\begin{tabular}{|c|l|l|c|}
\hline No & Conceptual Variable Relationship & \multicolumn{1}{|c|}{ Result } & \multicolumn{1}{c|}{ Source } \\
\hline 1 & $\begin{array}{l}\text { The Influence of Product } \\
\text { Attributes, Product Quality, and } \\
\text { Promotions on the Purchases of } \\
\text { Honda Brand Cars in Medan }\end{array}$ & $\begin{array}{l}\text { Product attributes, product quality, } \\
\text { partial and simultaneous promotion } \\
\text { have a significant effect on } \\
\text { purchasing decisions }\end{array}$ & $\begin{array}{c}\text { Aditi \& Hermansyur } \\
\text { (2018) }\end{array}$ \\
\hline 2 & $\begin{array}{l}\text { Predicting The Consumers } \\
\text { Purchase Intention of Durable } \\
\text { Goods: An Attribute -Level } \\
\text { Analysis }\end{array}$ & $\begin{array}{l}\text { Camera attribute like sensor, } \\
\text { display, image stabilization pursue } \\
\text { the consumer attention }\end{array}$ & $\begin{array}{c}\text { Bag, Tiwari, \& Chan } \\
\text { (2017) }\end{array}$ \\
\hline 3 & $\begin{array}{l}\text { Effect of Product Attributes on } \\
\text { Custom-made Brand Shoe } \\
\text { Purchase Decisions (Study on } \\
\text { Indonesian Custom-made } \\
\text { Trademarks) }\end{array}$ & $\begin{array}{l}\text { Product attributes have a positive } \\
\text { effect on purchasing decisions by } \\
\text { 48.5\%, }\end{array}$ & $\begin{array}{c}\text { Pradana \& Reventiary } \\
\text { (2016) }\end{array}$ \\
\hline 4 & $\begin{array}{l}\text { The effect of Product Attributes on } \\
\text { Purchase Decisions (Study of } \\
\text { Kawasaki-Bajaj Pulsar 200 Ns in } \\
\text { Bandar Lampung) }\end{array}$ & $\begin{array}{l}\text { Product features and product design } \\
\text { have a significant effect on } \\
\text { purchasing decisions. While the } \\
\text { product brand and product quality } \\
\text { have no significant effect on } \\
\text { purchasing decisions }\end{array}$ & $\begin{array}{c}\text { Siregar (2016) } \\
\end{array}$ \\
\hline
\end{tabular}


JEMA: Jurnal Ilmiah Bidang Akuntansi dan Manajemen, Vol. 16 No. 1 (2019)

http://riset.unisma.ac.id/index.php/jema (e-ISSN : 2597-4071)

\begin{tabular}{|c|l|l|c|}
\hline No & Conceptual Variable Relationship & \multicolumn{1}{|c|}{ Result } & Source \\
\hline 5 & $\begin{array}{l}\text { Analysis of the Effect of Price, } \\
\text { Product Quality, and Design on } \\
\text { the Purchasing Decisions of } \\
\text { Automatic scooter Type Honda } \\
\text { Motorcycle }\end{array}$ & $\begin{array}{l}\text { Price and product design affect the } \\
\text { purchasing decisions of Automatic } \\
\text { scooter Type Honda Motorcycle. } \\
\text { While the product quality has no } \\
\text { partial effect on purchasing } \\
\text { decisions. }\end{array}$ & Martini (2015) \\
\hline 6 & $\begin{array}{l}\text { Analysis of the Effect of Product } \\
\text { Attributes on Decisions of } \\
\text { Purchasing Suzuki Satria FU 150 } \\
\text { CC Motorcycle in Malang }\end{array}$ & $\begin{array}{l}\text { Partially, the product quality } \\
\text { variable is the only variable that is } \\
\text { proven to influence purchasing } \\
\text { decisions }\end{array}$ & $\begin{array}{c}\text { Anggipura \& } \\
\text { Yuniarinto (2013) }\end{array}$ \\
\hline
\end{tabular}

\subsection{Product Attributes}

Product attributes are the benefits that it will offer. These benefits are communicated and delivered by product attributes such as quality, features and style and design (Kotler \& Armstrong, 2014).

a) Product Quality is the ability of a product to provide performance in accordance with its function. Product quality is also defined as the characteristics of a product or service that is able to satisfy customer needs by determining the function of a product of good quality. (Tjiptono \& Chandra, 2016) product quality has eight dimensions as follows: Performance, Features, Reliability, Serviceability, Conformance to Specifications, Durability, Estethica, and Perceived Quality.

b) Product Features are competitive means to differentiate company products from competing products. (Putra \& Seminari, 2014) mentions that feature dimensions or indicators consist of a diversity of features, features according to expectations, and feature excellence. According to (Dewi \& Jatra, 2012) dimensions or indicators of product features consist of feature completeness, feature need, feature attraction and ease of use.

c) Product Design is a concept that is bigger than the style. (Kotler \& Armstrong, 2014) state the dimensions of product design consist of shape, features, quality, durability, reliability, easy to improve, and style.

\subsection{Purchase Decision}

Purchasing decisions are a process where consumers recognize the problem, find information about a particular product or brand and evaluate how well each of these alternatives can solve the problem, which then leads to purchasing decisions, according to (Tjiptono, 2014).

a) Choice of consumer products, which is the decision to buy a product or use the money for other purposes. In this case, the company must focus its attention on people who are interested in buying a product and the alternatives they are considering.

b) Choice of brands, in which the consumers must make decisions about the brand name that will be purchased, each brand has its own differences, in this case, the company must know how consumers choose a brand.

c) Choice of the distributor, the consumer must make a decision about which distributor to visit. Every consumer has different terms in determining the distributor, it can be due to the factor of location, low prices, complete inventory, convenience in shopping, the width of the place and others.

d) Time of purchase, the consumer's decisions in the choice of time of purchase can vary, for example, there are those who buy every day, once a week, once every two weeks and so 
forth.

e) Amount of purchases, the consumers can make decisions about how many products will be spent at a time. Purchases made may be more than one. Companies must prepare the number of products according to different desires.

f) Payment methods, the consumers can make decisions about the method of payment that will be made in using products or services

Based on the research framework and paradigm that researchers have made based on references, the researchers formulated the following hypothesis:

$\mathrm{H}_{1}$ : $\quad$ There is a positive effect between product attributes on purchasing decisions.

\section{RESEARCH METHOD}

\subsection{Research Design}

The research method is a scientific way to obtain data with specific purposes and uses (Sugiyono, 2017). The type of research used in this study was quantitative. This study used descriptive verification method that describes the influence of two or more different variables in accordance with the facts, the descriptive verification method is used to test product attributes on purchasing decisions. The data needed is data that is in accordance with the problems that exist and are in accordance with the objectives of the study, so that the influence between the variables examined through hypothesis testing can be found. The researchers conducted data analysis using SmartPLS 3.0 software. PLS (Partial Least Square) was chosen by researchers on the grounds that this data analysis method is based on the assumption that the sample does not have to be large (less than 100) to be analyzed and has residual distribution.

\subsection{Population and Sample}

The population taken in this study was the consumers of the HPCI (Honda PCX Club Indonesia) community KAPURSUCI (Karawang, Purwakarta, Subang, and Cikarang) of 150 members. It Consisted of Karawang Chapter: 70 members, Cikarang Chapter: 40 members, Purwakarta Chapter: 30 members, and Subang Chapter: 10 members. The number of samples is determined based on the calculation of the Solvin formula with an error tolerance level of $10 \%$, with 60 respondents. The sample collection method used in this study is non-probability sampling (accidental sampling). Non Probability Sampling is a sampling technique that does not provide the same opportunity for each population member to be selected as the sample. Accidental sampling is a technique for determining samples based on coincidence, that is, anyone who accidentally meets with a researcher can be used as a sample if he or she is deemed suitable as a data source (Sugiyono, 2017).

$n=\frac{N}{1+N(e)^{2}}$

Notes :

$\mathrm{n}=$ Number of samples

$\mathrm{N}=$ Number of populations

$\mathrm{e}=$ Presentage of error tolerance level of $10 \%$

So the calculation of the Solvin formulation in this study is as follows 


$$
\begin{aligned}
& n=\frac{150}{1+150(0,1)^{2}} \\
& n=60 \text { people }
\end{aligned}
$$

\subsection{Research Framework}

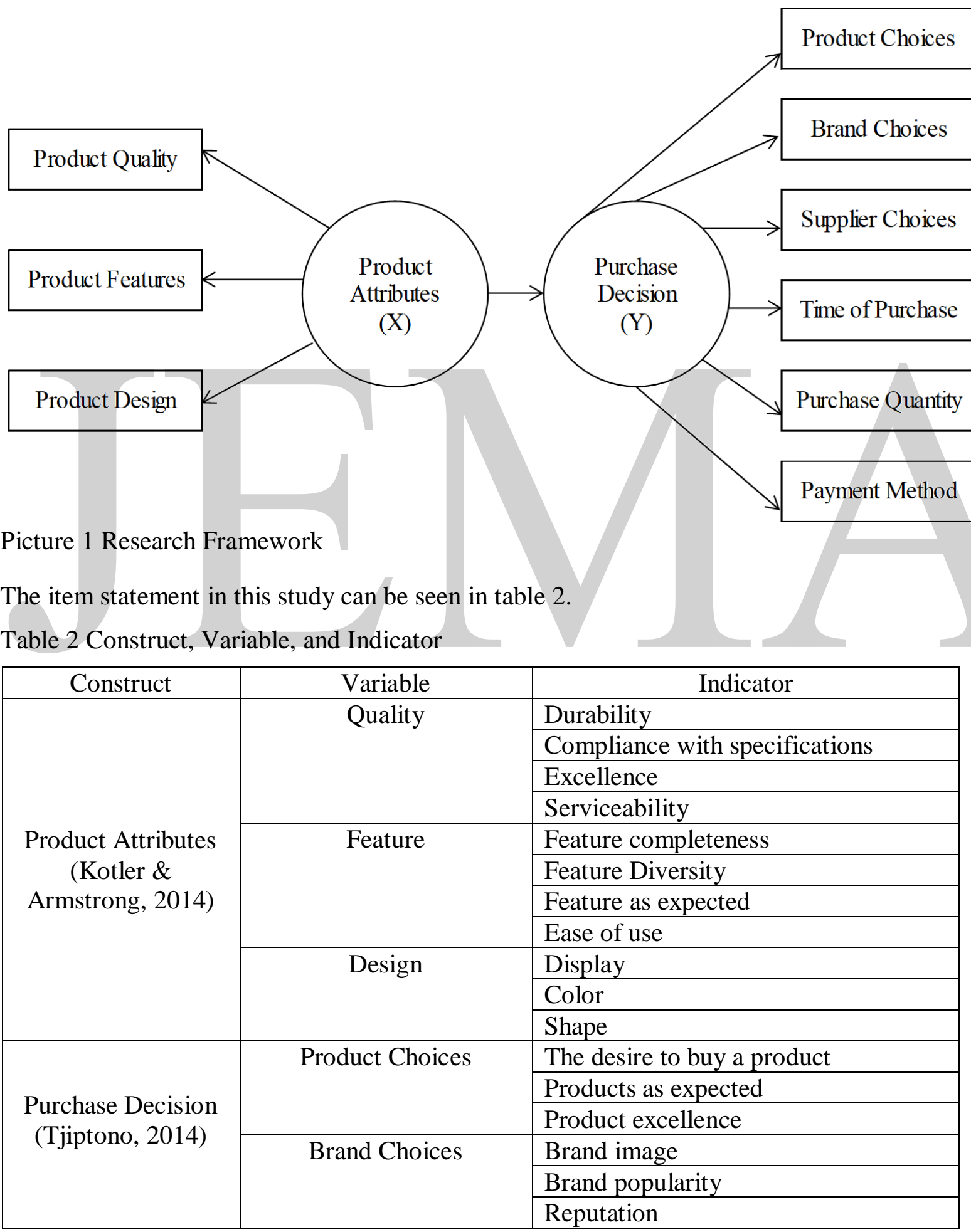


JEMA: Jurnal Ilmiah Bidang Akuntansi dan Manajemen, Vol. 16 No. 1 (2019)

http://riset.unisma.ac.id/index.php/jema (e-ISSN : 2597-4071)

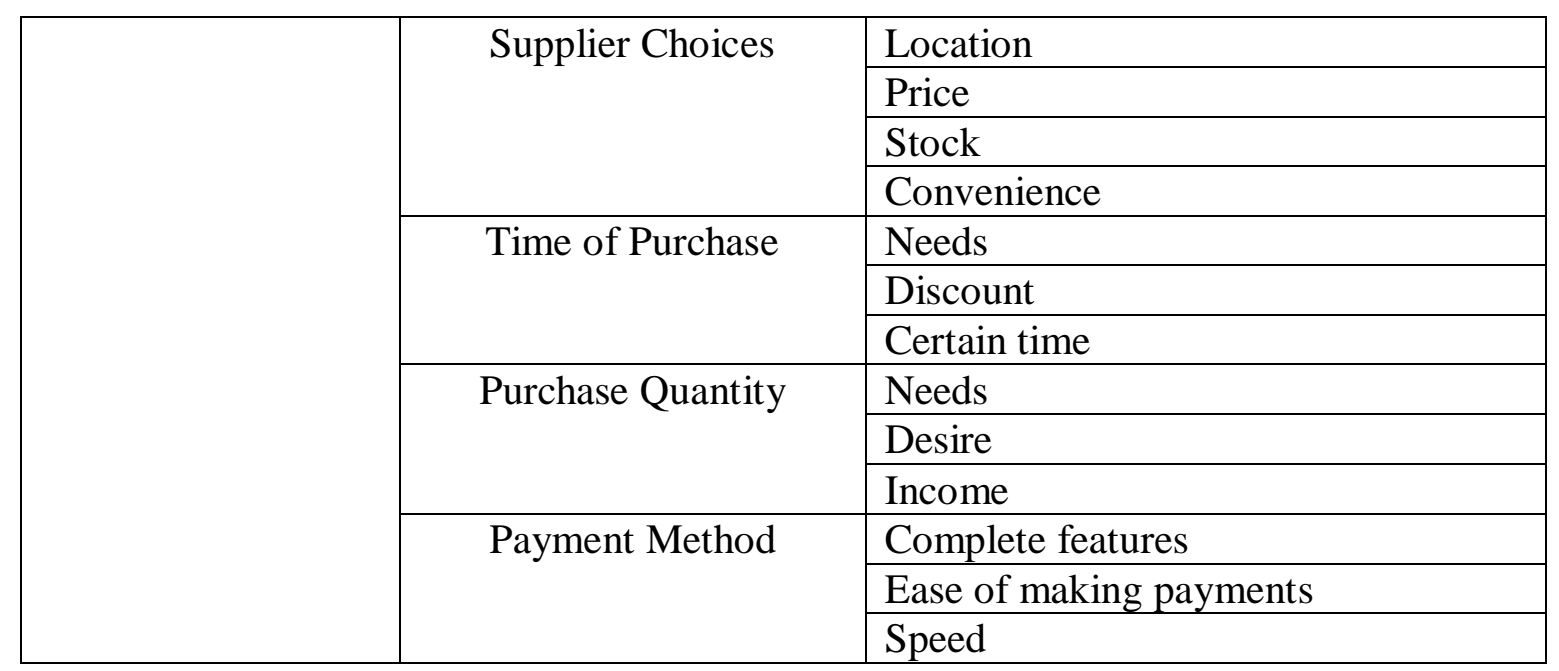

\section{RESEARCH RESULT AND ANALYSIS}

\subsection{Descriptive Analysis}

Table 3 Respondent Profile

\begin{tabular}{|c|l|c|c|l|c|}
\hline No & \multicolumn{1}{|c|}{ Description } & Percentage (\%) & No & \multicolumn{1}{c|}{ Description } & Percentage (\%) \\
\hline 1 & Gender & 88.3 & 3 & Income & \\
& Male & & IDR < 3 Millions & 18.3 \\
& Female & 11.7 & & IDR 3-5 Millions & 41.7 \\
2 & Occupation & & IDR > 5 Millions & 40 \\
& Student & 3.3 & & & \\
& Employee/Entrepreneur & 80 & & & \\
& Others & 16.7 & & & \\
\hline
\end{tabular}

Source: Primary Data Processed, 2018

Based on table 3 , it can be seen that the majority of respondents in this study are males who have a profession as private employees/self-employed with income of IDR 3 to 5 Million/Month.

\subsection{Validity and Reliability}

Validity test is intended to determine the validity of the questionnaire items used in data collection. The results of $r$ count then compared with the value of $r$ table with a significance coefficient $(\alpha)$ at the level of $5 \%$ or 0.05 . The value of $r$ table for the significance of 0.05 with $n=$ 60 and the testing for two directions is 0.2542 . So the statement is valid if the calculated $r$-value $\geq$ 0.2542 . The results of the calculation of validity in table 3 show that all items in the statement can be categorized as valid. 
JEMA: Jurnal Ilmiah Bidang Akuntansi dan Manajemen, Vol. 16 No. 1 (2019) http://riset.unisma.ac.id/index.php/jema (e-ISSN : 2597-4071)

Table 3 Validity Test Result

\begin{tabular}{|c|c|c|c|c|}
\hline Variabel & Item & $\mathrm{r}$ value & $\mathrm{r}$ table & Decision \\
\hline \multirow{11}{*}{$\begin{array}{c}\text { Variable X } \\
\text { (Product attributes) }\end{array}$} & Statement 1 & 0,531 & 0,2542 & Valid \\
\hline & Statement 2 & 0,601 & 0,2542 & Valid \\
\hline & Statement 3 & 0,539 & 0,2542 & Valid \\
\hline & Statement 4 & 0,628 & 0,2542 & Valid \\
\hline & Statement 5 & 0,466 & 0,2542 & Valid \\
\hline & Statement 6 & 0,599 & 0,2542 & Valid \\
\hline & Statement 7 & 0,608 & 0,2542 & Valid \\
\hline & Statement 8 & 0,623 & 0,2542 & Valid \\
\hline & Statement 9 & 0,620 & 0,2542 & Valid \\
\hline & Statement 10 & 0,458 & 0,2542 & Valid \\
\hline & Statement 11 & 0,594 & 0,2542 & Valid \\
\hline \multirow{19}{*}{$\begin{array}{c}\text { Variable Y } \\
\text { (Purchase Decision) }\end{array}$} & Statement 12 & 0,530 & 0,2542 & Valid \\
\hline & Statement 13 & 0,526 & 0,2542 & Valid \\
\hline & Statement 14 & 0,574 & 0,2542 & Valid \\
\hline & Statement 15 & 0,445 & 0,2542 & Valid \\
\hline & Statement 16 & 0,625 & 0,2542 & Valid \\
\hline & Statement 17 & 0,565 & 0,2542 & Valid \\
\hline & Statement 18 & 0,605 & 0,2542 & Valid \\
\hline & Statement 19 & 0,643 & 0,2542 & Valid \\
\hline & Statement 20 & 0,698 & 0,2542 & Valid \\
\hline & Statement 21 & 0,652 & 0,2542 & Valid \\
\hline & Statement 22 & 0,703 & 0,2542 & Valid \\
\hline & Statement 23 & 0,619 & 0,2542 & Valid \\
\hline & Statement 24 & 0,656 & 0,2542 & Valid \\
\hline & Statement 25 & 0,426 & 0,2542 & Valid \\
\hline & Statement 26 & 0,414 & 0,2542 & Valid \\
\hline & Statement 27 & 0,638 & 0,2542 & Valid \\
\hline & Statement 28 & 0,677 & 0,2542 & Valid \\
\hline & Statement 29 & 0,794 & 0,2542 & Valid \\
\hline & Statement 30 & 0,602 & 0,2542 & Valid \\
\hline
\end{tabular}

Source: Primary Data Processed, 2018

Furthermore, the test of the measurement model (inner model) also needed to be done to assess the validity and reliability of the model carried out with Convergent Validity, Composite Variables and Average Variance Extracted (AVE). 


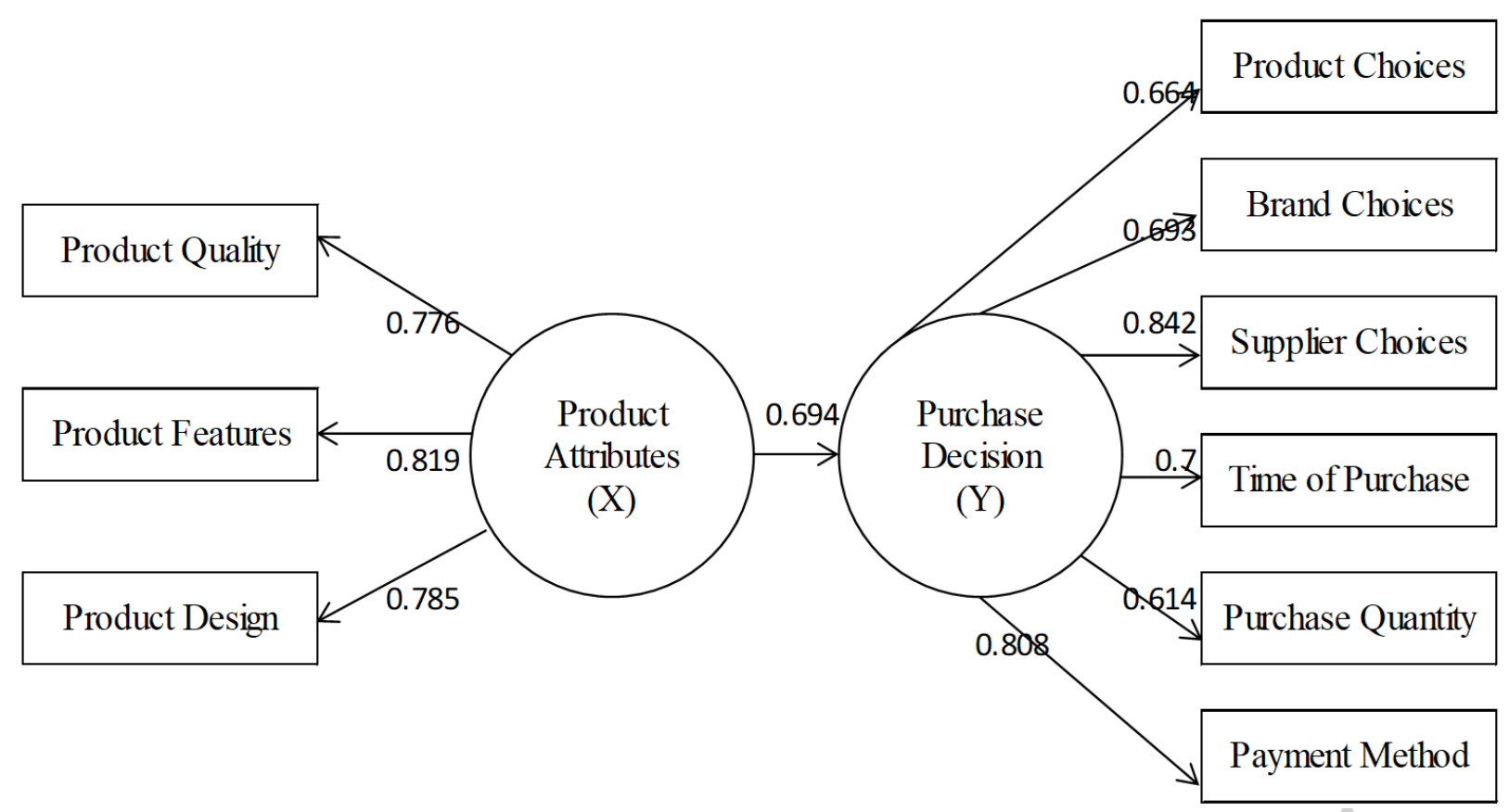

Picture 2 Outer Model (Primary Data Processed, 2018)

Ghozali (2014) states that the indicator is declared valid if it has a convergent validity value of 0.7 while the outer loading value that can still be tolerated is up to 0.5 . Based on Picture 2, it can be seen that all indicators have a value of $>0.5$ so it can be said that all indicators are valid. After testing the Outer Loading, then the construct reliability test was also conducted by measuring two criteria, reliability composite and Cronbach's alpha from the indicator block that measures the construct. The following are the reliability composite test results and Cronbach alpha from SmartPLS 3.0:

Table 4 Reliability Test

\begin{tabular}{|l|c|c|c|c|}
\hline Variable & Cronbach's Alpha & $\begin{array}{c}\text { Composite } \\
\text { Reliability }\end{array}$ & $\begin{array}{c}\text { Rule of } \\
\text { Thumb }\end{array}$ & Decision \\
\hline (X) Product Attributes & 0,786 & 0,822 & 0,60 & Reliable \\
\hline (Y) Purchase Decision & 0,896 & 0,868 & 0,60 & Reliable \\
\hline
\end{tabular}

Source: Primary Data Processed, 2018

Based on the results in the table above it can be concluded that all constructs have Cronbach's alpha value $>0.6$ and Composite reliability value $>0.7$ so that it can be seen that the construct has good reliability.

\subsection{Research Analysis}

To find out whether the hypothesis is accepted or rejected, P-Value was used at a significance of $5 \%$ or 0.05 . If the P-Value is $<0.05$, then $\mathrm{HO}$ is rejected, meaning there is an influence between the two variables studied. Conversely, if $\mathrm{P}-\mathrm{Value}>0.05$ then $\mathrm{H} 0$ is accepted, meaning that there is no influence between the two variables studied. The following are the results of the structural model evaluation obtained from Smart-PLS 3.0 Bootstrapping Report. 
Table 5 shows that the P-Values obtained in this study are $<0.05$, which means that H0 is rejected or in other words, it can be concluded that there is an influence between the observed product attributes on the purchasing decisions of $47.8 \%$.

Table 5 Bootstrapping Report Smart-PLS 3.0 test

\begin{tabular}{|l|c|}
\cline { 2 - 2 } \multicolumn{1}{c|}{} & P Values \\
\hline
\end{tabular}

Source: Primary Data Processed, 2018

Table 6 R-Square Result

\begin{tabular}{|l|r|}
\cline { 2 - 2 } \multicolumn{1}{c|}{} & R Square \\
\hline (Y) Purchase Decision & 0,478 \\
\hline
\end{tabular}

Source: Primary Data Processed, 2018

\subsection{Research Discussion}

Table 7 Product Attributes Dimension

\begin{tabular}{|c|l|c|c|c|}
\hline No & \multicolumn{1}{|c|}{ Dimension } & Total Scores & Ideal Total Scores & Percentage \\
\hline 1 & Product Quality & 1009 & 1200 & $84 \%$ \\
\hline 2 & Product Features & 1002 & 1200 & $84 \%$ \\
\hline 3 & Product Design & 771 & 900 & $86 \%$ \\
\hline \multicolumn{2}{|c|}{ Product Attributes } & 2782 & 3300 & $84 \%$ \\
\hline
\end{tabular}

Source: Primary Data Processed, 2018

Based on tables 7 and 8 , it can be seen that overall, the majority of respondents in this study have positive perceptions towards the offer of product attributes. Furthermore, the product choice dimension has the highest total score. Therefore, based on the explanation, it can be concluded that product design is the dominant factor or dimension that is most considered by respondents in evaluating product attributes. Meanwhile, the choice of products (the desire to buy products, product as expected, product excellence) becomes the dominant factor or dimension in the purchasing decisions on Honda PCX products that were used as the object of this study. The majority of respondents responded positively to the proposed purchase decision; this indicates that the creation of a purchasing decision on Honda PCX is only a matter of time. Moreover, the results of statistical tests show that there is a positive and significant influence between product attributes and the purchasing decisions of Honda PCX premium automatic scooters with R-Square value of $47.8 \%$. The results of this study reinforce the results of previous studies, including Aditi \& Hermansyur (2018), Bag, Tiwari, \& Chan (2017), Pradana \& Reventiary (2016), Siregar (2016), Martini (2015), Anggipura \& Yuniarinto (2013) which state that there are positive influences between product attributes and purchasing decisions. The more positive the assessment of a product attributes, the greater the chance of a purchasing decisions. 
JEMA: Jurnal Ilmiah Bidang Akuntansi dan Manajemen, Vol. 16 No. 1 (2019)

http://riset.unisma.ac.id/index.php/jema (e-ISSN : 2597-4071)

Table 8 Purchase Decision Dimension

\begin{tabular}{|c|l|c|c|c|}
\hline No & Dimension & Total Scores & Ideal Total Scores & Percentage \\
\hline 1 & Product Choices & 760 & 900 & $84 \%$ \\
\hline 2 & Brand Choices & 805 & 1200 & $67 \%$ \\
\hline 3 & Supplier Choices & 926 & 1200 & $77 \%$ \\
\hline 4 & Time of Purchase & 605 & 900 & $67 \%$ \\
\hline 5 & Purchase Quantity & 742 & 900 & $82 \%$ \\
\hline 6 & Payment Method & 740 & 900 & $82 \%$ \\
\hline \multicolumn{2}{|c|}{ Purchase Decision } & 4578 & 5700 & $80 \%$ \\
\hline
\end{tabular}

Source: Primary Data Processed, 2018

\section{RESEARCH CONCLUSION AND LIMITATION}

\subsection{Conclusion}

Product attribute variables were measured through the product quality dimension, product feature dimension, and product design dimension. The product design dimension has the highest average score which means that product attribute variables can be described through the design of the product offered. Purchasing decision variables are measured through product choice dimension, brand choice dimension, supplier choice dimension, Time of purchase dimension, purchase quantity dimension, and payment method dimension. Product choices dimension has the highest total score and time of purchase dimension has the lowest score which means that the purchasing decision variable can be described through the product choice dimension. There is a positive influence between product attributes and purchasing decisions with points of $47.8 \%$ and the remaining $52.2 \%$ is explained by other variables outside the research.

\subsection{Limitation}

This study has its limitations, it only looked at the product attribute in one conceptual. The next researcher is expected to conduct research that studies the characteristics of attribute in several categories of companies to provide better generalization.

\section{REFERENCES}

Aditi, B., \& Hermansyur, H. M. (2018). Pengaruh Atribut Produk, Kualitas Produk dan Promosi, Terhadap Keputusan Pembelian Mobil Merek Honda di Kota Medan, Jurnal Ilmiah Manajemen dan Bisnis, 19(1), 64-72. https://doi.org/10.30596/jimb.v19i1.1743.

Anggipura, E. A., \& Yuniarinto, A. (2013). Analisis Pengaruh Atribut Produk Terhadap Keputusan Pembelian Motor Suzuki Satria FU 150 CC di Kota Malang. Jurnal Ilmiah Mahasiswa FEB, 1(1). Retrieved from https://jimfeb.ub.ac.id/index.php/jimfeb/article/view/165.

Bag, S., Tiwari, M. K., \& Chan, F. T. S. (2017). Predicting The Consumers Purchase Intention of Durable Goods: An Attribute-Level Analysis. Journal of Business Research, 94, 408-419. https://doi.org/10.1016/j.jbusres.2017.11.031.

Dewi, N. L. G. D. N., \& Jatra, M. (2012). Pengaruh Atribut Produk Terhadap Keputusan Pembelian Handphone di Kota Denpasar, E-Jurnal Manajemen Universitas Udayana, 2(2), 248-261. Retrieved from https://ojs.unud.ac.id/index.php/Manajemen/article/view/4359. 
Fransiska, P. A., \& Seminari, N. K. (2018). Peran Citra Merek Dalam Memediasi Pengaruh Daya Tarik Iklan Terhadap Niat Beli Honda PCX 150, E-Jurnal Manajemen Universitas Udayana, 7(7), 3797-3826. https://doi.org/10.24843/EJMUNUD.2018.v07.i07.p13.

Ghozali, I. (2014). Structural Equation Modeling, Metode Alternatif dengan Partial Least Square (PLS) (4th ed.). Semarang: Badan Penerbit Universitas Diponegoro

Kotler, P., \& Armstrong, G. (2014). Principle Of Marketing (15 th). New Jersey: Pearson Prentice Hall.

Martini, T. (2015). Analisis Pengaruh Harga, Kualitas Produk, dan Desain Terhadap Keputusan Pembelian Kendaraan Bermotor Merek Honda Jenis Skutermatic. Jurnal Penelitian, 9(1), 113131. https://doi.org/10.21043/jupe.v9i1.854.

Pradana, M., \& Reventiary, A. (2016). Pengaruh Atribut Produk Terhadap Keputusan Pembelian Sepatu Merek Customade (Studi di Merek Dagang Customade Indonesia), Jurnal Manajemen 6(1), 1-10. https://doi.org/10.26460/jm.v6i1.196.

Putra, P. A. W., \& Seminari, N. K. (2014). Pengaruh Fitur, Layanan Pelengkap dan Garansi Terhadap Keputusan Pembelian Handphone (Studi Kasus pada Mahasiswa S1 Fakultas Ekonomi dan Bisnis Universitas Udayana Denpasar), E-Journal Manajemen Universitas Udayana, 2349-2362. Retrieved from https://ojs.unud.ac.id/index.php/Manajemen/article/view/8665.

Setiawan, F. H. A. (2013). Hubungan Antara Tingkat Ketertarikan Pada Elemen-Elemen Iklan Televisi Dengan Brand Knowledge (Studi Eksplanatif Hubungan antara Tingkat Ketertarikan pada Elemen-Elemen Iklan Televisi Yamaha Mio J Versi “ $1000 \%$ Joyful” dengan Pengetahuan Merek. Universitas Atma Jaya Yogyakarta.

Siregar, A. D. (2016). Pengaruh Atribut Produk Terhadap Keputusan Pembelian (Studi Pada Konsumen Produk Kawasaki-Bajaj Pulsar 200 NS di Kota Bandar Lampung). Universitas Lampung. Retrieved from http://digilib.unila.ac.id/23333.

Sugiyono, P. D. (2017). Metode Penelitian Pendidikan Pendekatan Kuantitatif, Kualitatif Dan $R \& D$. Bandung: Alfabeta.

Tjiptono, F. (2014). Pemasaran Jasa-Prinsip, Penerapan, dan Penelitian. Yogyakarta: Andi Offset.

Tjiptono, F., \& Chandra, G. (2016). Service, Quality, dan Satisfaction (4th ed.). Yogyakarta: Andi Offset.

*) Yudi Helfi, Department of Management, University of Singaperbangsa, Karawang, Indonesia (Email: yudi.helfi@fe.unsika.ac.id)

**) Fatihatul Akbar, Department of Management, University of Singaperbangsa, Karawang, Indonesia (Email: fatihatul.akbar16147@ student.unsika.ac.id)

***) Dinda Mutiara Pratiwi, Department of Management, University of Singaperbangsa, Karawang, Indonesia (Email: dinda.mutiara16112@student.unsika.ac.id)

****) Fakhri Mujahid Maolani, Department of Management, University of Singaperbangsa, Karawang, Indonesia (Email: fakhri.mujahid16144@student.unsika.ac.id) 